\title{
'A Return to the World': Diffraction and Truth-telling in Post- Cartesian IR
}

\author{
Liberty Chee \\ August 2021 Draft \\ libertychee@gmail.com
}

\begin{abstract}
This paper presents an ethics premised on a post-Cartesian ontology: that what we know is how we know and vice-versa. The acknowledgment of the IR scholar's constitutive relation to the world she seeks to describe, and of which she is a part, entails an ethics that is also a practice and an agency. I build on the notion of diffraction in Karen Barad's quantum theory and on Foucault's notion of parrhesia. In place of reflection, Barad offers diffraction as a nonrepresentationalist methodology which attends to the difference knowledge can make rather than the accuracy of our representations. Parrhesia is the 'third hermeneutic' which problematizes our relationship with the activity of knowing itself. In the pragmatist sense, we are asked not only to be of use to our communities, but to be mindful of who we are and what kind of subject we become in our inscriptions of the world. This diffractive research ethics addresses two problems in IR theory as they present in the conduct of fieldwork - the limits of reflexivity, notably the impossibility of objectively representing ourselves to ourselves, and the critique that the pragmatist concerns in the 'doing' of science pays insufficient attention to how power conditions knowledge production. I suggest that this ethic, which is a performance of our relation to truth, allows us to better realize the pragmatist ideal of a democratic social science by allowing us to resist the centripetal force of epistemic sovereignty.
\end{abstract}

Key words: diffraction, parrhesia, post-positivism, feminist science studies, quantum theory, ethics 


\section{Opening}

As of writing, deep in Covid-19 pandemic times, I opened a file containing fieldnotes from 2013: "Counselling - 'retraining', 'animal taming'. Some aspects of 'quality control' are inefficient. Even those who already have experience overseas are made to go through training." I had not looked at my fieldnotes in a few years and yet emotions welled. I had sharp memories of the day I had written them, of faces and places, even the sound of respondents' voices. I remembered sitting in a room, in a sparse building, off a suburb in Jakarta. My respondent ran a small NGO that provided services to Indonesian migrant workers. She herself had worked for some time in Saudi Arabia as a domestic worker. I remembered willing myself not to cry as she recounted her experience of having to work through the season of Ramadan with only a few hours of sleep at a time. It was not what she said but how she looked and how she spoke. Even recalling it now as I type on my keyboard, I feel distress.

The problems this paper engages with emerged out the practice of 'experience-near' methods, notably ethnography, in International Relations. There have been calls to venture out to the field to document how micro-actions constitute macro-phenomena for richer accounts of global politics. This was supposed to signal a turn towards more empirical work, away from meta-theoretical battles (Gould et al., 1984; MacKay and Levin, 2015; Neumann, 2002; Neumann and Neumann, 2015; Solomon and Steele, 2016). Apart from meeting empiricist demands or, indeed, 'provincializing' accounts of modernity (Vrasti, 2008), entreaties of 'a return to the world' (Abraham and Abramson, 2015: 2) make the scholar square with her constitutive relation to that world. This would entail not only a greater accountability to a community of scholars or usefulness to wider society, but a commitment to an ethical practice.

I address two responses to the implications of a 'post-Cartesian, post-individualist ontology (Mattern, 2011: 64-65)' in IR. Reflexivity is supposed to improve objectivity (Eagleton-Pierce, 2011; Mérand and Pouliot, 2008) as producers of knowledge attempt to reveal all possible subject-positions (Inayatullah, 2011) for a more complete reality (Hopf, 2007: 62-63). On the other hand, pragmatists call for us to bracket the 'truthfulness' of knowledge claims in lieu of praxis. Instead of aiming for accuracy in our representations, what we should do instead is to problematise and revalorise the practice of science as a vocation, with the end-goal of contributing to a more democratic society (Abraham and Abramson, 2015; Miettinen et al., 2009; S Sundaram and Thakur, 2019). 
Working Draft: Please do not cite or circulate without permission.

I argue that these responses give rise to two interrelated problems. A critique of reflexivity, that it is impossible to objectively represent ourselves to ourselves, resmuggles a dualist ontology (Knafo, 2015; Leander, 2011). On the other hand, the pragmatist prescription to 'interfere' in the world creates ethical problems of power/knowledge which would make it difficult to realise pragmatists' call for a more democratic social science. To come closer to realising the aim of democratising knowledge production entails a more careful look at the 'third hermeneutic' (Friedrichs and Kratochwil, 2009: 724), or the account of making knowledge claims, and to examine how relations of power condition knowledge production.

I suggest that one way of doing so builds on calls for a performative rather than a representationalist ethic and practice of making truth claims in International Relations (Zanotti, 2015). A shift from representation to performance means that the 'seeing' or mirroring metaphor is decentred, and, indeed, accepts the impossibility of the act of representing representation (Foucault, 2002: 17). What takes the place of panoptic omniscience is diffraction instead of reflection. Conventional approaches usually affirm the existence of only two - knowledge (or representations) and the known. Alternatively, there are three - knowledge, the known and the knower. Newtonian metaphysics and normal social science assume the three to be distinct.

A performance of truth, that is a performance of knowledge as a truth-claim troubles these separations - which Karen Barad understands to be an 'epistemologicalontological-ethical' framework (Barad, 2007: 26). This position states that epistemology cannot be separated from ontology, that what we know is how we know and vice versa. 'Reality' does not refer to a classical correspondence theory of truth. Instead, what corresponds are theories and 'agential reality' - the phenomenon which is the nondualistic aggregate of the processes of measurement and the object of study. Social constructivists dispute that science is the mirror of nature. There is the opposite argument that nature is all culture. Barad positions herself in between.

A diffractive approach to truth-telling takes note of how "our scientific understanding of nature [is] part of the nature to be understood (Rouse, 2004b: 145)." Where reflection (reflexivity) mirrors the same, diffraction attends to the difference we make in a specific inscription of a phenomenal world. As the missing third hermeneutic, a performance of 
Working Draft: Please do not cite or circulate without permission.

truth responds to the ethics of classical pragmatism (Cochran, 2002) which problematises the relationship of the knowledge producer with the 'known' she produces. Put differently, this deals with pragmatists' concern with the consequences of knowledge, not its foundations (Kaag and Kreps, 2012).

This methodology does not seek to expand the horizons of a single complete reality but instead attends to how we produce accounts of realities through our performances of knowledge production. It does not take for granted that these practices take place in relations of power, which entails a responsibility to our audience, to whom we are accountable and are therefore vulnerable. I supplement Barad's underspecified ethics, with Michel Foucault's notion of parrhesia. This is an ethics of knowing and being which seeks to reveal our relationship with reason, with logos (Foucault, 2011a: 144) to an audience. It sets out to "confront what one is thinking and saying with what one is doing, with what one is (Foucault, 1984: 374)."

To be responsible in this sense means recognizing our accountability as vulnerability, and not only in minding the ways we are 'commingled' with others and the world. It is rather a 'constitutive mode of openness' or a 'plastic potentiality (Gilson, 2011: 311).' To be vulnerable in this sense valorises openness to being affected as well as affecting others. It is different from the 'universal conscience' of the critical theorist who represents or speaks on the other's behalf. This ethic of responsibility does not refer to the 'invulnerable judgment' (Beattie and Schick, 2013: 13) of the expert who holds herself apart from the world she has objectively diagnosed and for whom she holds the cure. The inability or oversight to cede this position constitutes the impossibility of breaking Cartesian dualism.

Parrhesia is Foucault's attempt at disentangling the triangle of power - right - truth, what he describes as the melding of positivist science and raison d'état or the development of the state form, for a more democratic social science (Foucault, 2007: 50). It seeks to decentre the author, and in doing so guard against the desire for a sovereign science, "in which the rules of truth and the truths of rule are intimately connected (Dillon, 2017: 80)." Epistemic sovereignty is the equivalent of political sovereignty, where statements are legitimated as true through the elimination of irrationality, and indeed, where the rational method serves as the 'epistemic surrogate for law (Rouse, 1994: 103).' 
This interpretation of parrhesia deals primarily with the problem of power as it relates to the scholar's subjectivity. As such, it differs from Zanotti's mobilisation of parrhesia as 'micropolitical interventions' (Zanotti, 2017: 378), or the situated practice of the Foucault's 'specific intellectual' (Foucault, 1980b). Rather it meditates on the forward slash of power/knowledge, and what kind of stance we ought to take if making truth claims were no longer about representation. It contests the notion of Cartesian objectivity, where those who keep distance from power presumably keep distance from tyranny (Foucault, 1980a: 51). It stems from Foucault's Nietzschean reading of knowledge as a compromise between duelling passions and that because of this struggle, knowledge does not correspond with the world (Fujita, 2013). Parrhesia means caring for oneself (epimeleia heautou), and this means asking oneself whether one does know what one purports to know. It is also about exhorting others to do the same (Foucault, 2010: 326). Parrhesia's task is not one of representation but of becoming. That in speaking in front of others, we transform ourselves and, if they will accept our truth, transform our audience. The relationship between the speaker and the audience is what constitutes parrhesia as a performance.

Parrhesia is in service of self and co-governance, a care of the self and others. It offers us a way of knowing which does not mirror truth, but enjoins us to embody it by living what Foucault calls an alethes bios (Foucault, 2011a: 218), a true life. Foucault contrasts the Cynics from Plato for whom philosophy and monarchy are closely related. It seeks to undo epistemic sovereignty and moves closer to Foucault's lifelong project of 'cutting of the king's head' in political theory. To exert mastery over the self means being able to do the same over the kingdom. But Cynics would be kings in themselves. It is to be revealed to an 'internal gaze' which is divine in all of us (Foucault, 2011a: 270-275).

A diffractive ethical practice is a 'post-Cartesian account of agency (Mattern, 2011: 74)' that contests subsuming conduct in the realm of the scientific and epistemological. A diffractive methodology not only offers new insights to feminist science studies or scientific practices, but takes these and "diffracts them back onto the science itself (Barad, 2007: 36)." Most importantly, its understanding of the knowing subject is not one who reflects on but cares for herself, who attends to herself, and who transforms herself as she confronts power in seeking knowledge. 


\section{Optical Metaphors: From Reflection to Diffraction}

The days I fully understood that knowledge is produced by people and that I was training to become such a person was when I struggled with my first literature review. I did not understand that I needed to put myself in it and that the task was not simply to relay what has already been said and written. I needed to engage in conversation with the living and dead, to speak to authors and tell them, and my readers, what I thought about what they had said. It was a frightful moment. Frightful because until then it had not occurred to me that scholarship was a collective endeavour of acting, knowing and speaking subjects and that I was asking for a seat at the table.

Reflexivity was a response to a number of different problems in IR theorizing. It was supposed to offer a methodological alternative to positivism, and to advance critiques from the level of meta-theory (Hamati-Ataya, 2014). As most of the post-foundational energies were expended towards undermining positivism's epistemic dominance, critical IR scholars did not necessarily train reflexivity on themselves (Berling, 2015: 14). There were then moves to mine scholarly selves in autobiographies and autoethnographies (Brigg and Bleiker, 2010; Doty, 2010; Inayatullah, 2011; Löwenheim, 2010). Critical security studies worked to acknowledge that agency could be found everywhere, and that causality is emergent (Aradau et al., 2015; Salter and Mutlu, 2013). These all work towards undermining the scholar's authority and assertions, "which may appear as weakness to more traditional scholars (Salter and Mutlu, 2013: 2)." These attempts are supposed to "objectify the IR theorist for the purposes of enhancing the science of objectivity (Eagleton-Pierce, 2011)." Reflexivity was supposed to work as a kind of selfregulating mechanism that, because it reveals subject positions, is supposed to show us how our interests are 'interested', and allow us to disrupt the reproduction of social hierarchies (Leander, 2011: 306).

But how could one objectively objectify oneself? Samuel Knafo argues that the subject of reflexivity cannot be found in a specific 'place,' and that it is impossible to carry out Bourdieu's aim to make sociology more scientific by eliminating all possible biases through self-knowledge. The subject, (i.e. the scholar) does not pre-exist prior to the process of inquiry. Subjectivity and its effects can only be observed in practice. This is likely why, Knafo notes, those who gesture towards reflexive scholarship, even Bourdieu himself, are unable to explicitly show how reflexivity has an effect on the conduct of 
research or research outcomes. Worse, the latter never describes himself in a position of power even though he has had considerable influence in the French academy. As such, Knafo claims, reflexivity is treated as an ethic rather than meaningfully comprising methodology (Knafo, 2015).

Likewise, Vincent Pouliot's 'sobjectivism' neglects the person making sense of historicized intersubjective meanings (Pouliot, 2007). The Bourdieusian claim to more objectivity through reflexivity prompted Mérand and Pouliot to call Bourdieu a kind of 'hyperpositivist (Mérand and Pouliot, 2008: 608)'. However, this only addresses the relationship between the knower (subject) and the known (object). It does not take account of the effect of the process of knowing, and indeed knowledge, on the known, or what Karl Maton calls the epistemic relation. In this schema, knowledge is seen as the byproduct of the relation between subject and object (Maton, 2003). This is similar to Stefano Guzzini's reconstruction of constructivism based on Gidden's double hermeneutics - that interpretation happens at the levels of action and observation, i.e. in the lifeworld of those observed and in the community of observers. For Guzzini, reflexivity is meant to underscore the possibility that IR is a body of knowledge that is 1 ) part of social reality and 2) can possibly affect that reality (Guzzini, 2000).

The missing third hermeneutic attends to the activity of knowing itself. Even the most 'demanding' accounting of what counts as evidence in Ted Hopf's typology of epistemological positions (Hopf, 2007: 62-63) only asks that that the hermeneutic circle is expanded, where the author's inclusion of herself in the process of understanding is meant to achieve a more complete reality. Pragmatists and practice theorists side-step the problem of objectively objectifying oneself by reflecting instead on the relationship of the knower to the knowledge produced in practical contexts (Berling and Bueger, 2013). Pragmatism inserts the scholar in the world as knowing agents and practitioners, and seeks to bracket methodological and 'theoretical feuds,' in favour of a pluralistic social science (Bauer and Brighi, 2008: 165). A 'practical reflexivity' is envisioned to preserve the scholar's autonomy and the democratic engagement with the community in solving societal problems (Bueger and Gadinger, 2015: 457-458).

If modern scientific authority rests on "truth, certainty and universalism", how do scientists also question this truth while preserving "a place from where to speak (Berling 
and Bueger, 2013: 116)"? Drawing from various traditions in social theory, Berling and Bueger outline six strategies from which the knower might seek to negotiate her relation with the world, and as such take responsibility for the consequences of the knowledge she produces. The 'honest broker' (Pielke) gives as many policy options instead of justifying only one. The 'organic intellectual' (Gramsci) helps create counter-hegemony from within. The 'collective intellectual' (Bourdieu) forms a community who agree on methodology and a desire to challenge social laws. The 'curious expert' (Enloe), takes a quizzical stance rather than explains. The 'liberal ironist' understands the importance of science even as she constantly questions her position in it. Lastly, the 'situated expert' (Haraway) understands that "no knowledge is produced from a Kantian 'nowhere' (Berling and Bueger, 2013: 118)." And to be objective means being mindful of what is excluded in each semiotic-material configuration of truth.

Feminists theorists have of course long contested the formless, placeless, timeless Cartesian cogito (Alaimo and Hekman, 2008; Alcoff and Potter, 1993; Grasswick, 2011; Haraway, 1991). A view comes from some body at some place and some time. Following this tradition, Barad builds on Haraway's critique of reflexivity, notably the dominant view - quite literally - that knowing is seeing. Haraway expresses her discontent with reflexivity:

"Reflexivity has been much recommended as a critical practice, but my suspicion is that reflexivity, like reflection, only displaces the same elsewhere, setting up worries about copy and original and the search for the authentic and really real...What we need is to make a difference in material-semiotic apparatuses, to diffract the rays of technoscience so that we get more promising interference patterns on the recording films of our lives and bodies. Diffraction is an optical metaphor for the effort to make a difference in the world (Haraway, 2018: 16)."

Barad argues that representation "raised to the nth power does not disrupt the geometry that holds object and subject at a distance as the very condition for knowledge's possibility (Barad, 2007: 88)." Reflexivity still rests on the assumption that the knower, the known and the activity of knowing may be separated. It assumes that, being separable, one could not have effects on the other. Barad offers diffraction as a possible model for nonrepresentationalist methodological approaches. Like Haraway, Barad does not propose diffraction as a means by which we improve objectivity. It is not meant to represent the really real. Barad, like Haraway, is rather interested in the literal difference 
diffraction can make. For Barad, diffraction is an actual physical phenomenon. It can either be an object or an apparatus of investigation (Barad, 2007: 73).

Seeing also plays a role in Foucault's early investigations of representation and its limits. His detailed discussion of Las Meninas and over two dozen of Eduard Manet's works (Foucault, 2002, 2009) demonstrate that what the eye sees cannot always be faithfully translated on a two-dimensional plane, and that "...the profound invisibility of what one sees is inseparable from the invisibility of the person seeing - despite all mirrors, reflections, imitations, and portraits (Foucault, 2002: 17)." In other words, not only is distortion inevitable due to the limits of the canvas' Euclidean geometry and the specific physiology of the human eye, but the very act of distortion itself has been hidden. Abandoning faithful representation, Manet invents the 'painting-object' by playing with three elements - space, light and the viewer's location. As such he 'invents' the modern viewer whose experience of the painting-object "renders him conscious of his presence and of his position within a much larger system (Foucault, 2009: 17)." In playing with spatial relations, the source of light and the viewer's gaze, Manet broke the 'fourth wall' in his painting as performance.

Diffraction means seeing as scanning tunnelling microscopes (STM) - through refraction, not reflection. They do not simply magnify. Seeing with an STM is not like opening one's eyes or pressing a button. Rather, STMs form 'images' through the sense of touch. Seeing with an STM means knowing how to operate the instrument, experimenting with various set-ups, all kinds of 'non-theory-based manipulations' and learning as one does. Seeing requires practice. Representationalism brackets out the significance of these practices, or fails to account for them altogether (Barad, 2007: 53).

So, in place of reflection, diffraction. Where the former mirrors the same, the latter attends to difference. And where diffraction is the goal, experiments are not meant to test hypotheses but become "a means of mutating concepts and reassembling the world (De Freitas, 2017)." If the point is not simply to 'peer,' but to 'interfere' (Hacking, 1983: 189), then the interference consists not only in understanding that we could never fully 'see' ourselves as subjects of representation, but to mark a difference, where our "knowledgepractices [matter] here-and-now and not merely recording after-the-fact (Kaiser and Thiele, 2014: 166)." This marking of a difference means being responsible for what our 
knowledge practices do. It also means taking account of what our experimental apparatuses include and exclude.

Curiously, the content of Barad's ethics takes for granted that scientific practices, and the persons performing them, are not immune from the effects of power on knowledge and vice versa. Knowing, being a 'direct material engagement (Barad, 2007: 49)' with the world, entails being acted upon by others. Truth in this process is not something which corresponds to what really happened. For Foucault, truth-telling is a process of opposition or struggle, 'the space of the agon' (Foucault, 2013b: 76). Something is true if the speaker who makes its utterance is at risk, and understands herself to be implicated in systems of power relations and therefore strives for ethical scholarship.

\section{Participating in Realities}

Fieldwork journal entry, September 30, 2013. Singapore

...let me explain what it's like to elicit 'knowledge' from a respondent who may or may not have a history of inflicting cruelty on other beings. Firstly, it consists of playing supplicant. You are no inquisitor there to judge them guilty of crimes against humanity. What you offer is a listening ear, a chance for them to cleanse themselves of their sins. Second, be alert as to why they have chosen to reply to your e-mail/letter and have decided to allot a certain amount of time to speak with you. Some will do so out of a need to show that they have nothing to hide. This kind of respondent will give you time but reveal nothing. I'll say a category of respondents are experts in this tactic - let's call them diplomats. And yet others genuinely think they have done nothing out of ordinary and will speak to you out of a need to fluff their own egos. Look at me, this is what I have accomplished. Extracting knowledge from this kind is not difficult. The most dangerous kind of respondent, however, is also usually the one who has the most important things to say. The danger consists of convincing you not only of the facticity of their narrative but also inviting you to see through their eyes and understand from their perspective. They will convince you that they are good. The most difficult thing is to balance between doing precisely this kind of immersion - as any ethnographer would - and manage to extract oneself from it after the encounter. My respondent last Monday is an industry insider. She was instrumental in opening the Cambodian domestic worker market. She is a little old lady who gave me an hour before her meeting with other industry insiders at a hotel in Orchard. I like her. She is very smart, engaging, charming. She is kind. That day after consulting with her group she invited me to have lunch with them. As she introduced me to her people, she flattered me. She lay a gentle hand on my upper arm as I exchanged cards with one and shook the hand of another. 
Barad's 'ethico-ontoepistemology' (Barad, 1998) is inspired by physicist Niels Bohr's reflections on quantum phenomena. In her framework, objectivity relies on the 'agential separability' of the observed and the 'agencies of observation.' The latter is the term she borrows from Bohr in lieu of 'subject' to signify that there can be non-human agency and that agency is plural. More importantly, agency is not something an entity possesses but is the dynamic, constant reconfigurations of the world (Barad, 2007: 141). The 'measure' is that which separates the two, a "Cartesian-like cut between knower and known [which delineates] object from observational apparatus (Barad, 1996: 169)." The point of investigation then is this 'cut' and the apparatus which made it possible to examine, and indeed 'make real', the phenomenon under study. Barad points out that Bohr's writings would include intricately detailed drawings of experimental apparatuses (Barad, 1996: 172). This differs from classical physics' notion that the measure exists independent of the person doing the measuring and is an accurate reflection of that which it represents.

In Barad's methodology, to theorize is "not to leave the material world behind and enter the domain of pure ideas where the lofty space of the mind makes objective reflection possible. Theorizing, like experimenting, is a material practice (Barad, 2007: 55)." Objectivity does not mean standing outside the world, as this assumes the mind-body split. To be objective does not mean safeguarding detachment but to be able to respond to the indeterminacy of which elements of the research are doing what. Objectivity, in this case, is produced when one enacts the 'Bohrian cut'. What determines this cut that makes a phenomenon, which makes possible the determination of the object and the agencies of observation is the specification of the experimental or measurement apparatus. The apparatus is part of what is being described and if there are modifications to the set-up, the properties of the object will also change. It is not that the act of observation that modifies what is observed. It is the observing agencies that make the difference.

The apparatus, which is itself constructed as part of the specific material and theoretical circumstances, marks the subject-object distinction, where the object is the phenomenon. Again, Barad's 'objective' does not mean that the knower stands apart from the world in absolute exteriority. It means being able to make an 'agential separability' within the phenomenon itself, where the phenomenon is the entanglement or 'intra-action' of the object and measuring agencies which emerge from the intra-action that produces them. 
Again, they do not exist as discrete entities prior to the encounter (Barad, 2007: 118120), as Knafo has similarly pointed out. This agential separability that makes objectivity, and therefore science possible, are the configurations and enactments of the apparatus. It resolves 'ontological indeterminacy' in physics, i.e. it explains how in one experimental set-up light manifests as a particle and in another a wave.

Bohr's theory of knowledge is central to Barad's agential realism because the subjectobject distinction was key to his practice and understanding of quantum physics. For this it might be useful to understand the methodology that informs Barad. I draw primarily from Paul McEvoy's interpretation of Bohr's work (McEvoy, 2001). Bohr was forced to introduce a new epistemology to explain what could not be explained in classical physics (McEvoy, 2001: 5). Wave-particle duality could only be understood if light could somehow be observed as either wave or particle depending on the 'conceptual framework' one was using. Bohr calls this 'complementarity'. To describe light as a wave would include concepts like extension, amplitude and phase. These concepts would not apply if one were to describe light as a particle. For the latter, one would use localizability, mass, charge, etc. (McEvoy, 2001: 144-5). These concepts are built in the conceptual framework. In all, the whole experimental set-up allows for the what Bohr calls 'possibilities of description': the kinds of experiments that can be used to establish the value of a quantity in a given state. 'Possibilities of observation' are the kinds of observations that could be made on a particular system and experimental setting. In 1938, Bohr introduces the term 'phenomenon' to mean “observations made within a definite experimental context (McEvoy, 2001: 148)."

There are also two 'levels' where possibilities of description and observation could be made: at the macroscopic and microscopic levels. These levels are useful to illustrate what kind of knowledge claims could be made and communicated. For example, in the macroscopic world, we could study volume, temperature and pressure. In the microscopic particle world, there are no surfaces or volume, and no concept of boundary as in the former. Both levels, both 'realities' if you will, share time, position and momentum (McEvoy, 2001: 366-7). The crucial point of course is that there is a perceiving subject without whom there can be no variable experimental set-ups and no knowledge acquired and communicated. 
Who or what counts as a subject or an object is also variable, depending on who or what entity navigates, survives and thrives in the world by means of interfacing with specific objects. Beings with two eyes located in front of their bodies will probably interact with their environment very differently from those with four eyes (e.g. a jawless lamprey), six eyes (e.g. many types of spiders) or no eyes at all, as in Barad's brittle star (Barad, 2007: $375)$.

Lastly, Bohr's view about the implications of quantum theory is, according to McEvoy, instrumental as compared with the responses and position taken by his contemporaries, for example Einstein (McEvoy, 2001: 453). This instrumentalist view is ultimately about usefulness: “...statements are not true or false, but are either useful or not in formulating a successful description of and making descriptions (McEvoy, 2001: 455)." Of course there is evidence that suggests Bohr was influenced by pragmatist William James, especially in his concept of complementarity (Holton, 1970; Stephenson, 1986).

Here it is useful to contrast Barad's ethico-ontoepistemology from naturalism in the study of science, as explained by Joseph Rouse. In the latter, the way nature is conceived is 'anormative.' Whereas Barad claims that the way nature "as revealed by the sciences is itself normatively constituted (Rouse, 2004a: 146)." In other words, we inscribe our selves into our work not only as constructed subjects but as scholars in the active performance of research, and as subjects becoming, under ongoing construction, “composite, partial and always entangled (Mellander and Wiszmeg, 2016: 102)." Because we enact the world in this way and not that, then we are left with no choice but to account for our choices, to answer for when we include or exclude what comes to matter in our inscriptions of ourselves in the real. McEvoy argues that Bohr's position is not antirealism as such (Faye, 1991) but something that has been called 'participatory realism (Fuchs, 2017)', a 'participatory universe' (Wheeler, 1990), a 'participatory view of reality (McEvoy, 2001: 460-1)'. These argue that reality always exceeds what our science can capture.

Barad's ethics is one of responsibility, where the latter literally means the ability to respond to another being, "...of the entanglements of self and other, here and there, now and then (Barad, 2007: 394)." The question to ask is not only how we produce an ethical relation but how we ourselves are produced ethically (Hinton, 2013: 183). Where the 
Working Draft: Please do not cite or circulate without permission.

Cartesian notion founds agency in the doubting, self-reflecting subject, the implications of quantum theory would have us examine how existence instead gives rise to the cogito, "how thinking emerges in the process of the whole movement which we are already part of (Penttinen, 2018: 80)."

While Barad makes the case for it, the content of her ethics is underspecified. The reasons why we must be responsible are clear. But she does not say how, and to what end. She does not expound on what it means to be accountable or responsible. I echo Caroline Braunmuhl's critique of Barad conferring agency, and by definition ethics, to the nonhuman (Braunmühl, 2018). For example, it probably does not make sense to hold a disease responsible and accountable for doing what nature has designed for it to do. I follow Braunmuhl's distinction that ethical relations be confined to beings or entities capable of experience and suffering (Braunmühl, 2018: 230). Further, I take from Foucault the notion that ethics presupposes freedom - "a slave has no ethics (Foucault, 2013a: 286)." While the non-human does exercise agency, or in the vitalist sense the will to survive, it would be difficult to gauge whether it exercises freedom, ethics and therefore politics1.

New materialists and posthumanists in IR have likewise been inspired by developments in the philosophy of science in light of quantum phenomena. These approaches seek to decentre the human by expanding ontologies and scales, to include non-human processes and micropolitics to the planetary level (Connolly, 2013; Cudworth et al., 2018; Cudworth and Hobden, 2013; Lundborg and Vaughan-Williams, 2014). They hope to forge new ways of being and doing in an age of increasing complexity and interconnectedness, and a study of international relations that is post-Newtonian and non-anthropocentric. There have been multiple responses to 'quantize' IR in pluralist directions (Der Derian and Wendt, 2020; Murphy, 2021).

I share Laura Zanotti's prefacing of practices - an understanding of knowledge as knowhow which "results from commingling and doing together with others (Zanotti, 2019: 106)." Like pragmatists, she sees the scientific endeavour as a social activity with a purpose. Also inspired by Barad, her methodology is anti-substantialist and materialist,

1 It is beyond the scope of this paper to weigh in on interspecies or non-anthropocentric ethics, although there is already work on this in philosophy. 
as her ontology starts with phenomena. Our inquiries and ethical claims should stem from these phenomena as specific configurations of relations rather than substances (or context-free entities). Zanotti's ethics is 'stabilist' rather than foundationalist, building upon the work of Peg O'Connor (O'Connor, 2008). Using a house on a cliff as a metaphor, her ethical commitments relate to the goal of keeping the house stable, "adjusting the relations among its elements and with its environment (Zanotti, 2015: 292)." However, like pragmatists, this leaves her ethics open to the critique of paying insufficient attention to how power shapes us into a certain kind of subject to meet specific ends. Her Baradinspired ethics, also calls for us to be responsible. I hold that this responsibility means more than being accountable through our methodological mastery of truth claims. It is something other than getting our representations 'right (Dauphinee, 2010)'. This performance of truth, our account of relationship to logos as the third hermeneutic, opens up the world to contingency not only by marking a difference through our phenomenal cuts, and demonstrating how we have enacted the world through a specific configuration of our experimental apparatus, but by inviting our audience to be transformed by our truth-claims.

This is not the universal conscience of the critical theorist or the invulnerable judgment of the expert, but is oriented towards a commitment to a Foucauldian interpretation of 'Enlightenment' and 'Revolution' aimed at bringing about an 'other life' (autre vie) and an 'other world' (autre monde). The parrhesiast is not a vanguard but a practitioner, seeking to "change social life while being a part of it, exposed to others (Hardt, 2010: 33)." It does not mean telling truth to power as such, or even forming a 'counter-power' (Steele, 2010), but is a practice of constituting oneself as an ethical subject in the face of it. If what is left is the pragmatic desire to be of use, the question is how this can be done without oneself becoming a jurist, to call upon 'cold monsters' (Foucault, 2001: 417) to legislate and rule the mess away. Our relationship to logos, or performance of the third hermeneutic, needs to attend not only to how we can be of use to our communities, but that in our 'return to the world' we do not crown ourselves philosopher-kings (Foucault, 2011a: 52). Sovereignty, that is freedom, for the parrhesiast entails not only guaranteeing the professional autonomy of a community of practitioners (Berling, 2013; Bueger and Gadinger, 2015: 457; Franke and Weber, 2012: 676) but fully squaring with 
understanding how and in which ways we are entangled with others in relations of power.

\section{Truth-telling after the 'Cartesian Moment'}

My encounters with people, places and objects were mediated by my able body, whose meanings determined my experiences and capacities while in the field. Far from staging the "erotic fantasy of the ethnographer's penetration of the field" and not at all feeling like a returning 'hero' (de Lauretis 1984, 461), it took great pains preventing the metaphorical field (and indeed the actual people in it) from 'penetrating' me. Even as a 'modest witness', I returned home feeling burdened, and not a little disempowered by what I saw and was made to feel. Unlike other ethnographic accounts in $I R, I$ was not an insider who had privileged access to respondents. As an outsider making inquiries into an industry that has a reputation to be exploitative, my requests for an audience could not have been viewed benignly. As such I expended a lot of energy in managing my emotions, notably the feeling of fear and anxiety. These feelings stemmed from a tacit understanding that my research topic was politically sensitive, along with the risks of navigating unfamiliar cities as a lone female. Being identified as a Filipina also carried with it the burden of liminal identities when crossing borders or even everyday encounters. I had to manage the emotions of my respondents, by showing empathy and striving to understand their worldview, which included statements that I would otherwise have found objectionable. Having very little to bargain with for continued access other than their good will, the onus was on me to adjust and give way. I could not show offence, for example, when an Indonesian bureaucrat made a crude joke in my presence, something I would otherwise not have tolerated under different circumstances. Emotion work, along with hearing stories of abuse on a near-daily basis, would take a toll I had not expected. In retrospect, I now know I was not prepared to deal with emotions analytically. Fieldwork had marked me in ways I have not yet fully reckoned with.

What Foucault calls the 'Cartesian moment' was when philosophy was no longer about spirituality but about knowledge. It was when philosophy as an ethic, as 'care of the self' (epimeleia heautou) was displaced by 'know yourself' (gnothi seauton). For Foucault, this was a founding moment of modernity, in which knowledge is understood as gaining access to truth through rules of method and evidence (Foucault, 2004: 14-19). To be enlightened, or to attain enlightenment in this sense no longer meant salvation, but the "fulfilment in nothing else but the indefinite development of knowledge (Foucault, 2004: 18)." 
Foucault's critique of Enlightenment rationality is grounded in suspicion of positivist science and its relationship to statism or the 'science of the State.' At the heart of this critique is querying the relationships of "power, truth and the subject (Foucault, 2007: 57)." His lifelong task has been to uncover the links between coercion and elements of knowledge, not necessarily whether something is true or not, legitimate or not, scientific or not. Nevertheless, he has termed genealogy an 'anti-science (Foucault, 1980b: 169)." The goal is not to oppose the contents, concepts or methods of science, as such, but to oppose the centralisation of scientific discourse and to offer a "counter-positivism that is not the opposite of positivism but rather its counterpoint (Foucault, 2014: 21)." This is rooted in Foucault's understanding that this centripetal tendency can only ever be sovereignty, and a sovereign science that will illuminate the earth from a point that will not be located, a view from nowhere: "a pure gaze...capable of universality (Foucault, 2011a: 125)."

His suspicion that knowledge is compromised by raison d'état, or governmental reason is clear when he positions 'the sage' as masking operations of power, who is pure, and knows the order of things (Foucault, 2013b: 188-190). In his genealogies of the classics, he shows how purity became the justification for the distribution of power in the city for the distribution to be seen as natural and right: “...in the great political reorganisation and redistribution of the $7^{\text {th }}$ and $6^{\text {th }}$ centuries, a fictitious place was fixed where power is founded on a truth which is only accessible on guarantee of its purity (Foucault, 2013b: 193)." The pure/impure dichotomy came to be policed by religion, and eventually the state. Justice seeks out the criminal, the impure - and in so doing, constitutes state power and legitimacy over the city. By definition, popular power does not know the nomos or the law, and is excluded from knowledge. Democracy is impure.

Foucault is interested in an ethics that is impure. In place of the sage, he models his ethics in Diogenes the Cynic who performs his philosophy in a public arena as a "challenge, confrontation, derision, and criticism (Foucault, 2011b: 294)." Far from the shining example of the philosopher-king, Cynics are often held in contempt, portrayed as crude and lacking in culture (Foucault, 2011a: 196). Depictions of Cynicism indicate it was popularly practised and it took no special training or study to do so. Breaking from the Platonic model of truth-telling, Foucault does not mean for parrhesia to be addressed to the king, and as such does not mean to use philosophy to make law or prescribe political 
action. It is "truth-telling, in certain relation to political action; nothing more, nothing less (Foucault, 2011b: 286)." If parrhesia were a way of telling the truth, what makes it particular? It does not mean to demonstrate, persuade, teach or discuss. Demonstration means to give rational structure to an explanation. Persuading means resorting to rhetoric. It is not a transfer of knowledge, as in teaching, and neither is it a debate. In other words, parrhesia cannot be found in structures of discourse. Where do we find it? We find it where the act of truth-telling has a consequence for the truth-teller. The truth is in the effect that the speech act creates in the interlocutor - the one who listens. The parrhesiast tells the truth if she carries a risk for speaking (Foucault, 2011b: 52-56). It is not a performative utterance which has a calculated response - very different therefore from the interpretation of Steele in which parrhesia is utilitarian - meant to 'manipulate' the interlocutor (Steele, 2010: 104). Instead, the effect is contingent - the interlocutor may or may not accept the truth claim. And the danger lies precisely in this contingency - risking the rupture of the relationship.

The 'counterpoint' to the Cartesian catharsis of purification is not gnothi seauton (selfknowledge) but epimeleia heautou (care of the self). Epimeleaia heautou entails a selfmastery, a sovereignty that is not rooted in the reflecting cogito and is oriented towards Foucault's interpretation of the Enlightenment. His reading of Kant on the Aufklärung as the culmination of revolution precisely problematizes the difficulty of exiting tutelage, of reasoning for oneself when it is blocked by obedience to authority - of the king, the clergy and other eminent persons which, surely, include the universal intellectual (Foucault, 2011b). The task is neither to represent, nor to speak on others' behalf, but to "struggle against the forms of power that transform [us] into its object and instrument in the sphere of 'knowledge', 'truth', 'consciousness,' and 'discourse (Foucault and Deleuze, 1972: 208)'."

Sovereignty in parrhesia is not knowledge of the self, but care of the self, which also entails the care of others. For the Cynics, a philosopher's task is to “take care of men's care (Foucault, 2011a: 302)." Truth is a practice, embodied in one's conduct. Thus, traces of Cynicism can be found in Christian ascetic practices of mendicancy, going barefoot, taking a vow of poverty and wandering. It is a life that is 'militant', a "battle and struggle against and for self, against and for others (Foucault, 2011a: 283)." The task of Cynic veridiction or truth-telling, in its performance, is to show others an other life in order to 
bring forth an other world. Parrhesia is an ethical practice which understands that recognizing that we are caught in webs of power/knowledge is the guarantee of our own freedom. Where modern forms of power seek to shape us towards certain ends, and to be a certain kind of subject, a 'hyperpolitcised consciousness' (White, 1988: 199) must militate against what we are enjoined to become, to resist who we are.

What kind of ethics is required of a science "grounded in not knowing as a way of moving into a nonauthoritarian authority (Lather, 2017: 302)?" I suggest that it requires not only recognising the limits of what we can know, and being mindful of what is excluded in our phenomenal cuts, but what kind of participant we bring forth in our inscriptions of a world. I suggest that the diffractive practice in which truth is embodied by the speaker offers the possibility of change in ways the Bourdieusian subject may be not be able to (Hopf, 2017). Bourdieu's subject is different from Foucault's. Bourdieu's practice theory is one of the reproduction of domination in which change can only come exogenously. Whereas Foucault's genealogy of ethics is interested in "processes of becoming, of ethical visions but also ethical revisions (Faubion, 2012: 71)." They are knowing subjects in the way Bourdieu's are not. This is an ethics of becoming that seeks to transform an audience through its performance. That in witnessing the unspeakable, taking the risk to speak of it, the author relinquishes sovereign authority and instead forges a relation to those who would show courage to hear her truth-claim.

A diffractive ethical practice is not meant for us to know ourselves, but to care for ourselves (epimelea hautou) because in doing so we recoup what is lost in power/knowledge. We achieve a different relationship to truth - not as its faithful chronicler nor as an epistemic sovereign. What we gain is a relationship to truth that is political, that has something at stake, that is, by definition difficult to valuate (commodifiy) because it is dangerous. Cynic militantism, unlike other types practised in Antiquity, was public - aimed at everyone. It aspired to change the world. Here the function of politeia, of government, is not "just a question of war and peace, of duties, taxes and revenues in a city, but of happiness and misfortune, the freedom and slavery of the whole of humankind (Foucault, 2011a: 303)." A diffractive ethical practice is above all an exercise of freedom and autonomy by understanding in which ways we are entangled with others in relations of power. Apart from an ethics of knowing, it is also an ethics of becoming which seeks to unravel the ways striving for knowledge conscripts us

\footnotetext{
L.Chee. 'A Return to the World' $19 \mid 26$
} 
to be mortal sovereigns, little philosopher-kings. It is a practice of militancy that is not just about making strategic truth-claims "to try to strengthen some epistemic alignments, and to challenge, undermine or evade others (Rouse, 1994: 112)." It is also about finding new ways to govern ourselves and each other, indeed to fashion ways to "not be governed so much (Foucault, 1996: 384).”

\section{Closing}

Readers, colleagues, asked why I had taken myself out of the draft of this paper that they had read in March 2021. From where did my thinking emerge? Where were my 'selves' in it? Why did I choose to forgo speaking about my positionality? Why not write in a way that would let my readers follow me in my experience? Why not articulate more extensively the frustration that had triggered this paper? Why, indeed, did I take *myself* out of it? I thought about my answer. Was it because when I first started writing this paper in 2017, I was at the margins, in faraway Manila, where I could speak about the core of knowledge production without any real consequence?

The process of overcoming the limits of representation means dealing with a world in its continuous unfolding, a world that is alive and full of potentialities. In Barad's quantum world, agency is an enactment, not a property to possess, nor an intention as in the liberal tradition. In "weakening our confidence in homogenous and univocal truth (Flynn, 1987: 223)," we open up the world to new possibilities. The 'trick' that is the erasure of representation is precisely the erasure of vulnerability in a phenomenal world. If we are entangled in our instruments of knowing, the implications are that we practice radical responsibility for our engagement in and of the world. This responsibility is not only an ethic of accountability by demonstrating methodological mastery of our truth claims (techne), or the critical stance that these claims are always already implicated (Cox, 1981: 129), but what we are enjoined to do once we have 'returned' to the world.

I suggest that a diffractive ethical practice is a performance of our relation to truth, a third hermeneutic called for by Friedrichs and Kratochwil (2009). This practice seeks not only to distinguish Bohrian cuts to lay out our experimental apparatus, that is, the ways by which we are entangled in the knowledge we produce, but also to mark a 'difference' in public as testament to an other life, already present. This is a mode of veridiction that is not interested in adjudicating the really real but is one that invests and embodies the truth in the speaker through her agonistic encounter with the world. 


\section{References}

Abraham KJ and Abramson Y (2015) A pragmatist vocation for International Relations: The (global) public and its problems. European Journal of International Relations 23(1): 1-24. DOI: 10.1177/1354066115619018.

Alaimo S and Hekman S (2008) Material Feminisms. DOI: 10.2307/j.ctt16gzgqh.1.

Alcoff L and Potter E (1993) Feminist Epistemologies. New York \& London: Routledge. DOI: $10.1057 /$ fr.1994.56.

Aradau C, Huysmans J, Neal A, et al. (2015) Critical Security Methods: New Frameworks for Analaysis. London: Routledge.

Barad K (1996) Meeting the universe halfway: Realism and social constructivism without contradiction. Feminism, Science and the Philosophy of Science. DOI: 10.1007/978-94-009-1742-2_9.

Barad K (1998) Getting Real: Technoscientific Practices and the Materialization of Reality. Differences: A Journal of Feminist Cultural Studies 10(2): 87. DOI: Article.

Barad K (2007) Meeting the Universe Halfway: Quantum Physics and the Entanglement of Matter and Meaning. Durham \& London: Duke University Press.

Bauer H and Brighi E (2008) Pragmatism in International Relations. Pragmatism in International Relations. Available at: http://www.scopus.com/inward/record.url?eid=2-s2.084917043961\&partnerID=tZOtx3y1.

Beattie A and Schick K (2013) The Vulnerable Subject: Beyond Rationalism in International Relations. New York: Palgrave Macmillan.

Berling TV (2013) Knowledges. In: Bourdieu in International Relations: Rethinking Key Concepts in IR. Oxon and New York: Routledge, pp. 59-77.

Berling TV (2015) The International Political Sociology of Security: Rethinking Theory and Practice. The International Studies Encyclopedia. London and New York: Routledge. DOI: 10.1111/b.9781444336597.2010.x.

Berling TV and Bueger C (2013) Practical Reflexivity and Political Science: Strategies for Relating Scholarship and Political Practice. PS: Political Science \& Politics 46(01): 115-119. DOI: 10.1017/S1049096512001278.

Braunmühl C (2018) Beyond hierarchical oppositions: A feminist critique of Karen Barad's agential realism. Feminist Theory 19(2): 223-240. DOI: $10.1177 / 1464700117741243$.

Brigg M and Bleiker R (2010) Autoethnographic International Relations: exploring the self as a source of knowledge. Review of International Studies 36(03): 779-798. DOI: $10.1017 /$ S0260210510000689.

Bueger C and Gadinger F (2015) The Play of International Practice. International Studies Quarterly 59(3): 449-460. DOI: 10.1111/isqu.12202. 
Cochran M (2002) Deweyan Pragmatism and Post-Positivist Social Science in IR. Millennium - Journal of International Studies 31(3): 525-548. DOI: 10.1177/03058298020310030801.

Connolly WE (2013) The 'New Materialism' and the Fragility of Things. Millenium: Journal of International Studies 41(3): 399-412.

Cox RW (1981) Social Forces, States and World Orders: Beyond International Relations Theory. Millennium - Journal of International Studies 10(2): 126-155. DOI: 10.1177/03058298810100020501.

Cudworth E and Hobden S (2013) Of Parts and Wholes: International Relations beyond the Human. Millennium - Journal of International Studies 41(3): 430-450. DOI: $10.1177 / 0305829813485875$.

Cudworth E, Hobden S and Kavalski E (2018) Posthuman Dialogues in International Relations. Oxon and New York: Routledge.

Dauphinee E (2010) The ethics of autoethnography. Review of International Studies 36(03): 799-818.

De Freitas E (2017) Karen Barad's Quantum Ontology and Posthuman Ethics: Rethinking the Concept of Relationality. 23(9): 741-748.

Der Derian J and Wendt A (2020) 'Quantizing international relations': The case for quantum approaches to international theory and security practice. Security Dialogue 51(5): 399-413.

Dillon M (2017) Political Spirituality: Parrhesia, Truth and Factical Finitude. In: Bigo D, Gros F, and Bonditti P (eds) Foucault and the Modern International: Silences and Legacies for the Study of Politics. New York: Palgrave Macmillan, pp. 79-96.

Doty RL (2010) Autoethnography - making human connections. Review of International Studies 36(04): 1047-1050. DOI: 10.1017/S026021051000118X.

Eagleton-Pierce M (2011) Advancing a Reflexive International Relations. Millennium 39(3): 805-823. DOI: 10.1177/0305829811402709.

Faubion JD (2012) Foucault and the Genealogy of Ethics. In: A Companion to Moral Anthropology, pp. 67-84. DOI: 10.1002/9781118290620.ch4.

Faye J (1991) Niels Bohr: His Heritage and Legacy: An Anti-Realist View of Quantum Mechanics. Dordrecht \& Boston: Kluwer Academic Publishers.

Flynn T (1987) Foucault as Parrhesiast: His Last Course at the College de France (1984). Philosophy \& Social Criticism 12(2-3): 213-229.

Foucault M (1980a) Power/Knowledge: Selected Interviews and Other Writings 19721977. New York: Pantheon Books.

Foucault M (1980b) Truth and Power. In: Power/Knowledge: Selected Interviews \& Other Writings 1972-1977, pp. 109-133.

Foucault M (1984) The Foucault Reader. New York. DOI: 1984.

Foucault M (1996) What is Critique. In: Schmidt J (ed.) What Is Enlightenment? 
Eighteenth Century Answers and Twentieth-Century Questions. San Francisco, CA: University of California Press, pp. 382-398.

Foucault M (2001) Essential Works of Foucault 1954-1984 Volume 3: Power. Faubion JD (ed.). New York: The New Press.

Foucault M (2002) The Order of Things: An Archaeology of the Human Sciences. A Companion to Foucault. New York: Routledge.

Foucault M (2004) The Hermeneutics of the Subject: College de France Lectures 1981 1982. New York: Picador.

Foucault M (2007) The Politics of Truth. Los Angeles: Semiotext(e).

Foucault M (2009) Manet and the Object of Painting. London: Tate Publishing.

Foucault M (2010) The Government of Self and Others: Lectures at the College de France 1982-1983. Houndmills, Basingstoke, Hampshire \& New York: Palgrave Macmillan.

Foucault M (2011a) The Courage of Truth: The Government of Self and Others II. Houndmills, Basingstoke, Hampshire \& New York: Palgrave Macmillan.

Foucault M (2011b) The Government of Self and Others: Lectures at the College de France, 1982-1983 (Lectures at the Collège de France). 1982-1983. DOI: 10.1073/pnas.0703993104.

Foucault M (2013a) Ethics: Subjectivity and Truth: The Essential Works of Foucault 19541984 Vol. I. New York: The New Press.

Foucault M (2013b) Lectures on the Will to Know, Lectures at the Collège de France, 1970-1971.: 432. DOI: 10.1057/9781137044860.

Foucault M (2014) Wrong-Doing, Truth-Telling: The Function of Avowal in Justice. Chicago: The University of Chicago Press.

Foucault M and Deleuze G (1972) Intellectuals \& Power : A conversation between Michel Foucault and Gilles Deleuze. Language CounterMemory Practice selected essays and interviews by Michel Foucault: 205-217. DOI: 10.1007/s13398-0140173-7.2.

Franke U and Weber R (2012) At the Papini hotel: On pragmatism in the study of international relations. European Journal of International Relations 18(4): 669-691. DOI: $10.1177 / 1354066111404444$.

Friedrichs J and Kratochwil F (2009) On Acting and Knowing: How Pragmatism Can Advance International Relations Research and Methodology. International Organization 63(4): 701-731. DOI: 10.1017/S0020818309990142.

Fuchs C (2017) On Participatory Realism. In: Durham I and Rickles D (eds) Information and Interaction: Eddington, Wheeler, and the Limits of Knowledge. Cham, Swtizerland: Springer, pp. 113-134.

Fujita K (2013) Force and Knowledge: Foucault's Reading of Nietzsche. Foucault Studies 16: $116-133$.

Gilson E (2011) Vulnerability, Ignorance, and Oppression. Hypatia 26(2): 308-332. 
Gould M, Knorr-Cetina K and Cicourel A V. (1984) Advances in Social Theory and Methodology: Toward an Integration of Micro- and Macro-Sociologies. Contemporary Sociology. DOI: 10.2307/2068942.

Grasswick H (2011) Feminist Epistemology and Philosophy of Science: Power in Knowledge. London and New York: Springer. DOI: 10.1007/978-1-4020-6835-5_9.

Guzzini S (2000) A Reconstruction of Constructivism in International Relations. European Journal of International Relations. DOI: 10.1177/1354066100006002001.

Hacking I (1983) Representing and Intervening: Introductory Topics in the Philosophy of Natural Science. Cambridge, UK: Cambridge University Press.

Hamati-Ataya I (2014) Transcending objectivism, subjectivism, and the knowledge inbetween: the subject in/of 'strong reflexivity'. Review of International Studies 40(01): 153-175. DOI: 10.1017/S0260210513000041.

Haraway D (1991) Simians, Cyborgs, and Women: The Reinvention of Nature. Contemporary Sociology. New York: Routledge. DOI: 10.2307/2076334.

Haraway D (2018) Modest_Witness@Second_Millenium.FemaleMan@_Meets_OncoMouse. 2nd ed. New York \& London: Routledge.

Hardt M (2010) The Militancy of Theory. South Atlantic Quarterly 110(1): 19-35. DOI: 10.1215/00382876-2010-020.

Hinton P (2013) The Quantum Dance and the World's 'Extraordinary Liveliness': Refiguring Corporeal Ethics in Karen Barad's Agential Realism. Somatechnics 3(1): 169-189. DOI: $10.3366 /$ soma.2013.0084.

Holton G (1970) The Roots of Complementarity. Daedalus 99(4): 1015-1055.

Hopf T (2007) The Limits of Interpreting Evidence. In: Lebow RN and Lichbach MI (eds) Theory and Evidence in Comparative Politics and International Relations. New Jersey: Palgrave Macmillan, pp. 55-84.

Hopf T (2017) Change in International Practices. European Journal of International Relations 24(3): 687-711.

Inayatullah N (2011) Autobiographical International Relations: I, IR. London and New York: Routledge.

Kaag J and Kreps S (2012) Pragmatism's contributions to international relations. Cambridge Review of International Affairs 25(2): 191-208. DOI: 10.1080/09557571.2012.678297.

Kaiser BM and Thiele K (2014) Diffraction: Onto-epistemology, quantum physics and the critical humanities. Parallax 20(3): 165-167. DOI: 10.1080/13534645.2014.927621.

Knafo S (2015) Bourdieu and the dead end of reflexivity: On the impossible task of locating the subject. Review of International Studies 2(2016): 1-23. DOI: $10.1017 /$ S0260210515000121.

Lather P (2017) (Post) Critical Methodologies : The Science Possible After the Critiques. 
Oxon and New York: Routledge.

Leander A (2011) The promises, problems, and potentials of a Bourdieu-inspired staging of international relations. International Political Sociology 5(3): 294-313. DOI: 10.1111/j.1749-5687.2011.00135.x.

Löwenheim 0 (2010) The 'I' in IR: an autoethnographic account. Review of International Studies 36(July 2010): 1023-1045. DOI: 10.1017/S0260210510000562.

Lundborg T and Vaughan-Williams N (2014) New Materialisms, Discourse Analysis, and International Relations: A Radical Intertextual Approach. Review of International Studies (2015): 1-23. DOI: 10.1017/S0260210514000163.

MacKay J and Levin J (2015) Hanging Out in International Politics: Two Kinds of Explanatory Political Ethnography for IR. International Studies Review 17(2): 163188. DOI: $10.1111 /$ misr.12208.

Maton K (2003) Pierre Bourdieu and the Epistemic Conditions of Social Scientific Knowledge. Space and Culture 6(1): 52-65.

Mattern JB (2011) A Practice Theory of Emotion in International Relations. In: Adler E and Pouliot V (eds) International Practices. Cambridge, UK: Cambridge University Press, pp. 63-84.

McEvoy P (2001) Niels Bohr: Reflections on Subject and Object. San Francisco, CA: Microanalytix.

Mellander E and Wiszmeg A (2016) Interfering with others - Re-configuring Ethnography as a Diffractive Practice. Kulturstudier 1: 93-115.

Mérand F and Pouliot V (2008) Le monde de Pierre Bourdieu: Éléments pour une théorie sociale des Relations internationales. Canadian Journal of Political Science / Revue canadienne de science politique 41(3): 603-625. DOI: 10.2307/25166293.

Miettinen R, Samra-Fredericks D and Yanow D (2009) Re-Turn to Practice: An Introductory Essay. Organization Studies 30(12): 1309-1327. DOI: 10.1177/0170840609349860.

Murphy MPA (2021) Quantum Social Theory for Critical International Relations Theorists. Quantum Social Theory for Critical International Relations Theorists. DOI: 10.1007/978-3-030-60111-9.

Neumann CB and Neumann IB (2015) Uses of the Self: Two Ways of Thinking about Scholarly Situatedness and Method. Millennium - Journal of International Studies 43(3): 798-819. DOI: 10.1177/0305829815576818.

Neumann IB (2002) Returning Practice to the Linguistic Turn: The Case of Diplomacy. Journal of International Studies 31(3): 305-8298. DOI: $10.1177 / 03058298020310031201$.

O'Connor P (2008) Morality and Our Complicated Form of Life: Feminist Wittgensteinian Metaethics. University Park, PA: Pennsylvania State University Press.

Penttinen E (2018) Potential of posthumanist onto-epistemology for the study of international relations. In: Cudworth E, Hobden S, and Kavalski E (eds) Posthuman 
Dialogues in International Relations. Oxford \& New York: Routledge, pp. 72-88.

Pouliot V (2007) 'Sobjectivism': Toward a constructivist methodology. International Studies Quarterly 51(2): 359-384. DOI: 10.1111/j.1468-2478.2007.00455.x.

Rouse J (1994) Power/Knowledge. In: Gutting G (ed.) The Cambridge Companion to Foucault. Cambridge, UK: Cambridge University Press, pp. 92-114.

Rouse J (2004a) Barad's Feminist Naturalism. Hypatia 19(1): 142-161. DOI: 10.1111/j.1527-2001.2004.tb01272.x.

Rouse J (2004b) Barad’s Feminist Naturalism. Hypatia 19(1): 142-161.

S Sundaram S and Thakur V (2019) A pragmatic methodology for studying international practices. Journal of International Political Theory: 1-19. DOI: $10.1177 / 1755088219879177$.

Salter M and Mutlu C (2013) Research Methods in Critical Security Studies: An Introduction. New York: Rout. DOI: 10.1111/j.1467-8527.2007.00388_4.x.

Solomon T and Steele BJ (2016) Micro-moves in International Relations theory. European Journal of International Relations: 1-25.

Steele BJ (2010) Defacing Power: The Aesthetics of Insecurity in Global Politics. Michigan: University of Michigan Press.

Stephenson W (1986) William James, Niels Bohr, and Complementarity I - Concepts. The Psychological Record 36: 519-527.

Vrasti W (2008) The Strange Case of Ethnography and International Relations. Millennium 37(2): 279-301. DOI: 10.1177/0305829808097641.

Wheeler J (1990) Information, physics, quantum: the search for links. In: Zureck WH (ed.) Complexity, Entropy, and the Physics of Information. Boca Raton, FL: CRC Press.

White SK (1988) Poststructuralism and Political Reflection. Political Theory 16(2): 186208.

Zanotti L (2015) Questioning universalism, devising an ethics without foundations: An exploration of international relations ontologies and epistemologies. Journal of International Political Theory 11(3): 277-295. DOI: 10.1177/1755088214555044.

Zanotti L (2017) Reorienting IR : Ontological Entanglement, Agency , and Ethics. International Studies Review 19: 362-380. DOI: 10.1093/isr/viw044.

Zanotti L (2019) Ontological Entanglements, Agency and Ethics in International Relations: Exploring the Crossroads. Oxon and New York: Routledge. DOI: $10.4324 / 9781315227764$. 